\title{
Functional outcome of elbow after comminuted radial head fractures treated with radial head excision arthroplasty versus radial head prosthesis
}

\author{
Priyambada Kumar*, Nitin S. Patil, Mithilesh A. Nikam
}

Department of Orthopaedics, Krishna Institute of Medical Sciences, Karad, Maharashtra, India

Received: 11 January 2022

Accepted: 07 February 2022

\section{*Correspondence:}

Dr. Priyambada Kumar,

E-mail: priyambada.k94@gmail.com

Copyright: ( $)$ the author(s), publisher and licensee Medip Academy. This is an open-access article distributed under the terms of the Creative Commons Attribution Non-Commercial License, which permits unrestricted non-commercial use, distribution, and reproduction in any medium, provided the original work is properly cited.

\section{ABSTRACT}

Background: Aim of the study was to compare the functional outcome of the elbow after treating a Mason type III radial head fractures with radial head excision arthroplasty versus radial head arthroplasty with prosthesis and to study the complications which occur in both techniques.

Methods: This prospective study comprised of 30 patients, with each group comprising of 15 patients each $(n=15)$. Randomization was done; group A comprised of patients with Mason type 3 radial head fractures treated with excision arthroplasty and group B included patients with Mason type 3 radial head fractures treated with radial head arthroplasty with prosthesis. Post operatively the operated limb was immobilized in an above-elbow plaster of Paris slab for 3 weeks in all patients.

Results: Mean disabilities of the arm, shoulder and hand (DASH) score at 6 weeks was noted to be 30.13 for patients belonging to group A and 13.06 for patients in group B. The mean DASH score at 3 months follow up was calculated as 22.53 for group A and 10.66 for group B. The mean DASH score at 6 monthly follow up was noted to be 13.86 for patients in group A and 5.2 for patients in group B.

Conclusions: As evident from the radiological findings and the clinical follow up, it is safe to say that radial head arthroplasty with prosthesis produces more convincing results in terms of stability of the elbow joint, range of motion and pain as compared to radial head excision arthroplasty for the treatment of Mason type III radial head fractures.

Keywords: Radial head, Excision arthroplasty, Radial head prosthesis, Mason classification

\section{INTRODUCTION}

Radial head fractures account for up to $25-44 \%$ of all the elbow fractures. Frequency of this injuries has been noted to be higher in women and between the age group of 3040 years. ${ }^{1}$ A fall onto an outstretched hand in a pronated position, which causes an axial load across the elbow, is the most common mechanism of injury. Both the capitellum and the proximal ulna articulate with the radial head. The radio-capitellar joint's radial surface is convex and covered by articular cartilage. The sigmoid notch articulates with 280 degrees of the rim of the head, which is covered by thick hyaline cartilage, whereas the non- articulating arc is covered by thinner cartilage. ${ }^{2,3}$ The radial head has a poor blood supply, with a single extraosseous artery entering via the bare area. ${ }^{4}$

The radial head is a secondary valgus stabiliser of the joint which helps with axial force transmission through the elbow during flexion. ${ }^{5}$ It also functions as a varus and external rotatory constraint. ${ }^{6}$ The radial head is the principal stabiliser against valgus and compressive forces after the medial collateral ligament (MCL) is disrupted..$^{7-9}$ As a result, radial head excision exacerbates valgus instability in the event of an MCL injury. Furthermore, the radial head has been found to limit posterolateral, axial, 
and varus loading. ${ }^{10-12}$ During treatment, restoring radiocapitellar contact is crucial for coronal plane and longitudinal stability. ${ }^{13}$ Comminuted radial head fractures usually occur as part of a complicated injury, and typically have several mobile fragments with no soft tissue envelope. This fracture pattern is frequently associated with osseous and ligamentous injuries of the elbow and forearm. ${ }^{14}$ It is crucial to assess for associated injuries both clinically and radiologically. The pivot shift test for posterolateral instability and valgus/varus strain testing should be essentially performed.

The radial head is a fundamental link that provides for the intrinsic stability of the elbow through a synergistic relationship between a bony foundation and its surrounding soft tissue. Injury to the radial head causes substantial functional limitations as well as structural instability. According to multiple studies, the radial head is responsible for roughly $30 \%$ of the valgus stability of the elbow. The key objective of surgical intervention is to restore the radio-humeral link, which is critical for joint alignment and stability, in order to prevent recurrent subluxation or dislocation of the elbow joint. ${ }^{15,16}$

Mason categorized these injuries according to their severity in $1954 .{ }^{17}$ There are four different types of radial head fractures, as described by him. Broberg and Morrey later modified this to add the displacement and size parameters. $^{18}$ The classification scheme described by Mason is depicted in Table 1.

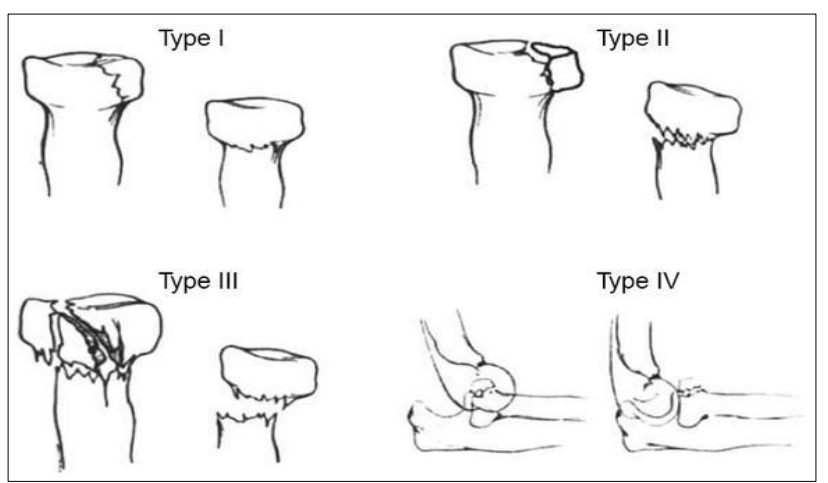

Figure 1: Mason's classification of radial head fractures.

Table 1: Mason classification of radial head fractures.

\begin{tabular}{|c|c|}
\hline $\begin{array}{l}\text { Mason } \\
\text { classification }\end{array}$ & Fracture characteristics \\
\hline Type I & $\begin{array}{l}\text { Undisplaced segmental/marginal } \\
\text { fracture; intra-articular displacement } \\
<2 \mathrm{~mm}\end{array}$ \\
\hline Type II & $\begin{array}{l}\text { Displaced segmental fracture } \\
\text { Intra-articular displacement }>2 \mathrm{~mm} \text { or } \\
\text { angulated }\end{array}$ \\
\hline Type III & Comminuted fracture \\
\hline Type IV & $\begin{array}{l}\text { Fracture associated with posterior } \\
\text { dislocation }\end{array}$ \\
\hline
\end{tabular}

Radial head injuries range from isolated low-energy slightly displaced fractures to high-energy impacted and comminuted fractures with osseo-ligamentous disruption. The radial head fracture causes structural and functional instability in the elbow, and therefore must be replaced, repaired, or excised depending on the situation.

The mainstay in the treatment of type III fractures has been radial head excision with or without prosthetic replacement. Comminuted radial head fractures are commonly treated with radial head excision and replacement. The occurrence of more than three pieces in the setting of an unstable radial head fracture has a bad prognosis, and radial head resection or replacement may be the best option if adequate fixation cannot be performed.

Comminuted fractures have traditionally been treated with radial head excision. Studies have refuted the notion that the radial head is an expendable skeletal component. A coronoid fracture and MCL insufficiency are both contraindications to excision.

The use of a prosthetic replacement allows for an anatomical reconstruction that preserves the elbow's stability and physiologic kinematics. However, oversizing or overstuffing the radial head prosthesis, or malpositioning the prosthesis, may result in a high rate of complications and surgical failure. Metal prosthesis have been found to have greater compressive rigidity and can withstand forces generated across the elbow. ${ }^{19-21}$ Monobloc and modular implant systems are available. Traditional monobloc designs are more technically demanding, but modular systems allow the surgeon to adjust the height and diameter to allow for more precise reconstruction..$^{22,23}$ A bipolar design is also available, which enhances capitellar tracking, increases radiocapitellar contact areas, and lowers joint contact pressures. ${ }^{24,25}$ However, There is not enough evidence to document that bipolar implants provide superior stability. ${ }^{26}$

The purpose of this study is to assess the outcome of elbow function in Mason type III radial head fractures treated with radial head excision arthroplasty versus hemiarthroplasty with radial head prosthesis, as well as the complications that occur with both techniques.

\section{METHODS}

This randomised prospective study comprised of 30 patients and was conducted at the department of orthopaedics, Krishna Institute of Medical Sciences, Karad from August 2020 to February 2021. Ethical clearance was obtained from the institutional ethical committee.

\section{Inclusion criteria}

Patients above 18 years of age, Mason's type III radial head fracture, non-geriatric adult population of either sex, 
and patients presenting within 2 weeks of injury were included.

\section{Exclusion criteria}

Patients with compound fractures, pathological bone condition, skeletal immaturity, previous history of fracture or ligamentous injury to the same elbow, concomitant fracture in the ipsilateral upper limb, already diagnosed with osteoarthritis of the elbow, and DRUJ disruption were excluded.

Clinical and radiological evaluation was done in each patient. Randomization was done and 15 patients were included in each group. Group A $(n=15)$ consisted of patients with Mason type III radial head fracture who underwent radial head excision arthroplasty and group B $(n=15)$ consisted of patients who were treated with radial head prosthesis. Informed and written consent was obtained in each case at the start of the study.

For both procedures, the patient was placed in supine position on the operating table with shoulder abducted, elbow in 90 degrees flexion and the forearm in mid-prone. The procedure was performed under general anaesthesia. Sterile scrubbing, painting and draping was done. Lateral curvilinear skin incision was taken. Superficial dissection was performed by dissecting the subcutaneous tissue in line with the skin incision. Fracture site was exposed using Kocher's interval between extensor carpi ulnaris and anconeus mucles (Figure 2). ${ }^{27}$

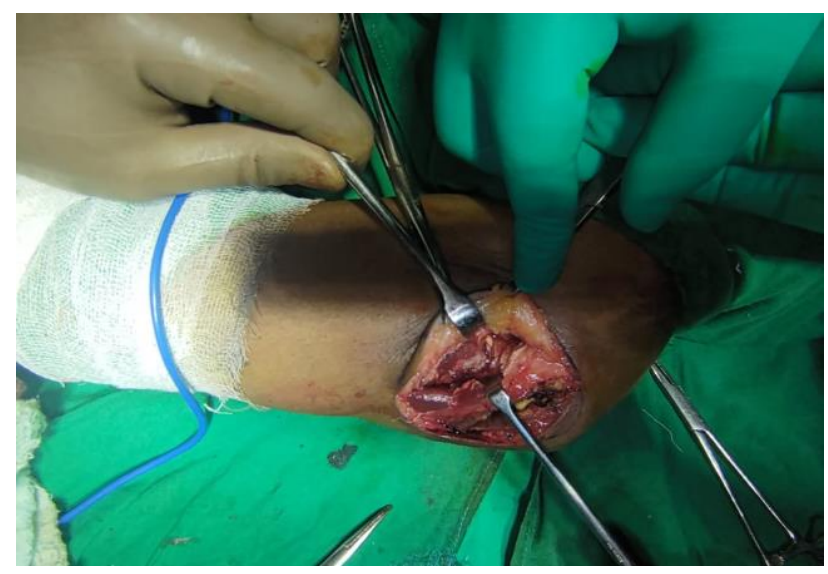

Figure 2: Exposing the fracture site via Kocher's interval between extensor carpi ulnaris and anconeus muscle.

It was ensured that the forearm was fully pronated to protect the posterior-interosseous nerve. After exposure, the comminuted fracture fragments were removed, taking care not to further damage the annular ligament. The fracture fragments were arranged on a side table to ensure that all the fragments have been removed from the joint (Figure 3). The radial neck was smoothened and trimmed if needed with a rongeur.

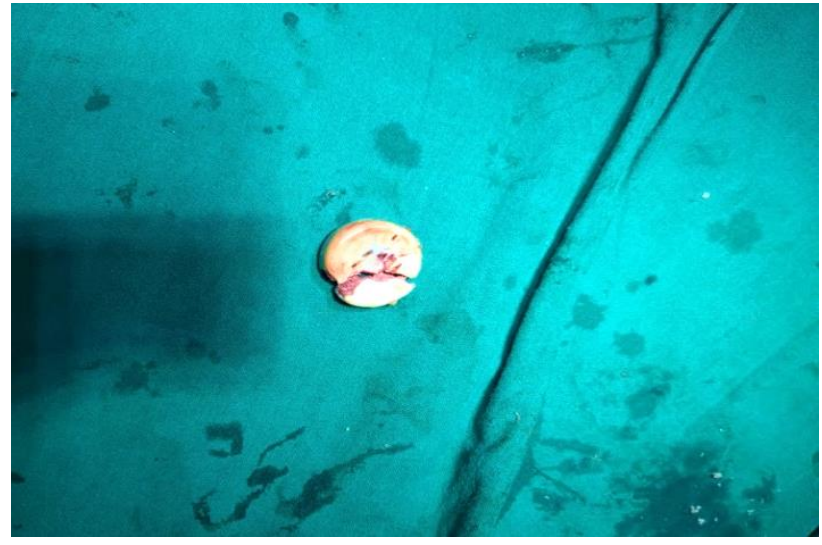

Figure 3: Radial head reconstructed over a side table after excision.

For patients in excision arthroplasty group, the annular ligament was then repaired with non-absorbable sutures. Elbow range of motion and structural stability was confirmed.

For patients in the prosthesis group, an awl was inserted into the medullary cavity to ensure snug fitting of the prosthesis stem. The ideal size of the radial head prosthesis needed was determined by reconstructing the excised radial head fragments. If the size of the native head was found to be in between two sizes, the small sized prosthesis was used. The prosthesis was then inserted and its tracking was confirmed in flexion, extension, pronation and supination. Integrity of the DRUJ was confirmed under fluoroscopy and annular ligament was repaired with nonabsorbable sutures.

Soft tissue and skin closure was done in layers (Figure 4).

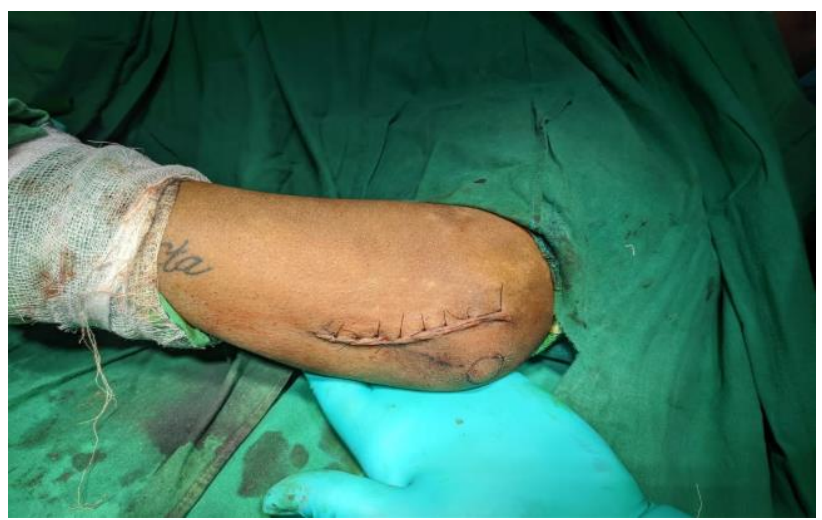

Figure 4: Skin closure.

An above elbow posterior POP slab was given to all patients with the elbow placed in supination for 3 weeks post-operatively following which rehabilitation exercises were started. The patients were called for follow up at 6 weeks, 3 months and 6 months post-operatively. At each follow up, all patients were evaluated using plain radiographs of the elbow joint in antero-posterior and lateral views and using the disability of arm, shoulder and 
hand (DASH) score to asses elbow function and range of motion. ${ }^{28}$

All data was entered in Microsoft excel spreadsheet and variables was analysed using statistical package for the social sciences (SPSS) software. Continuous variables are presented as mean \pm standard deviation (SD). Intergroup comparisons were made using the unpaired student's t-test for normally distributed variable. All hypothesis tests were two-tailed. A value of $\mathrm{p}<0.05$ was considered statistically significant.

\section{RESULTS}

The baseline characteristics of the composition of the two groups were similar. The demographic data is described in Table 2. In the present study, the patients were in the age group between 25-40 years of age. The mean age in group A was $32.4 \pm 3.1$ years and in group B was $29.8 \pm 3.3$ years. 20 male patients and 10 female patients participated in the study. Right side was predominantly involved in this study.

Table 2: Demographic data in both groups.

\begin{tabular}{|lll|}
\hline Parameters & $\begin{array}{l}\text { Group A (radial } \\
\text { head excision } \\
\text { arthroplasty) }\end{array}$ & $\begin{array}{l}\text { Group B } \\
\text { (radial head } \\
\text { prosthesis) }\end{array}$ \\
\hline Mean age & $32.4 \pm 3.1$ & $29.8 \pm 3.3$ \\
\hline Male/female & $9 / 6$ & $11 / 4$ \\
\hline Right/left & $11 / 4$ & $12 / 3$ \\
\hline
\end{tabular}

Mean DASH score at 6 weeks was noted to be $30.13 \pm 4.2$ for patients belonging to group A (treated with radial head excision arthroplasty) and $13.06 \pm 3.9$ for patients in group B (those who underwent hemiarthroplasty with radial head prosthesis) $(\mathrm{p}=0.04)$. The mean DASH score at 3 months follow up was calculated as $22.53 \pm 3.9$ for group A and $10.66 \pm 3.2$ for group $B(p=0.01)$. The mean DASH score at 6 monthly follow up was noted to be $13.86 \pm 2.8$ for patients in group A and $5.2 \pm 1.7(\mathrm{p}=0.01)$ for patients in group $\mathrm{B}$ (Table 3).

Table 3: DASH score at each follow up in both groups.

\begin{tabular}{|lll|}
\hline Parameters & $\begin{array}{l}\text { Group A (radial } \\
\text { head excision } \\
\text { arthroplasty) }\end{array}$ & $\begin{array}{l}\text { Group B } \\
\text { (radial head } \\
\text { prosthesis) }\end{array}$ \\
\hline 6 weeks & $30.13 \pm 4.2$ & $13.06 \pm 3.9$ \\
\hline 3 months & $22.53 \pm 3.9$ & $10.66 \pm 3.2$ \\
\hline 6 months & $13.86 \pm 2.8$ & $5.2 \pm 1.7$ \\
\hline
\end{tabular}

DASH score was significantly better for patients treated with hemiarthroplasty with radial head prosthesis as compared to patients treated with radial head excision arthroplasty at each follow-up follow-up.
Two of the fifteen patients who underwent radial head excision were noted to have developed osteoarthritis of the elbow and peri-articular ossification during the final review. One out of fifteen patients reported to have osteoarthritis in the radial head prosthesis group. Five out of the fifteen patients in the radial head excision group were noted to have proximal radial migration and persistent wrist pain, whereas only one case with proximal radial head migration and persistent wrist pain was reported in the prosthesis group. Four out of fifteen patients in the radial head excision group reported with postero-lateral instability whereas only one such case was observed in radial head prosthesis group. No cases with posterior interosseous nerve palsy and loosening of prosthesis were reported in our study (Table 4).

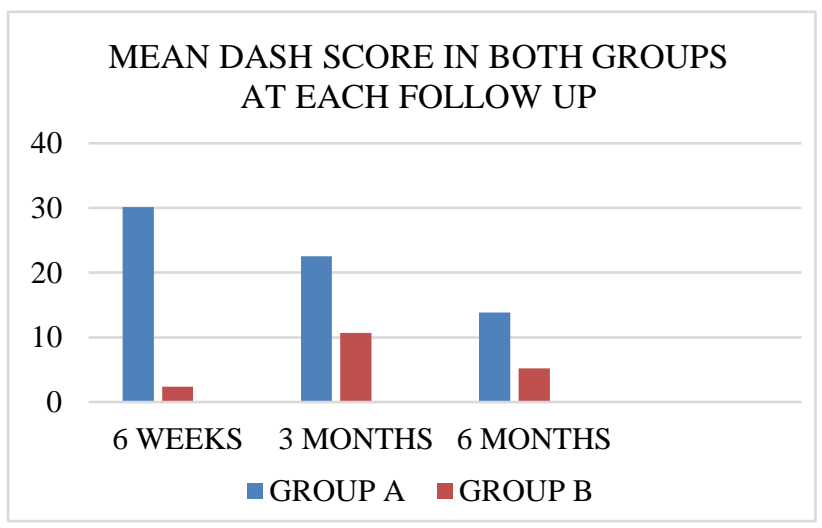

Figure 5: Mean DASH score in both groups at each follow up.

Table 4: Complications.

\begin{tabular}{|lll|}
\hline Complications & $\begin{array}{l}\text { Group A } \\
\text { (radial head } \\
\text { excision) } \%\end{array}$ & $\begin{array}{l}\text { Group B } \\
\text { (radial head } \\
\text { prosthesis) } \%\end{array}$ \\
\hline $\begin{array}{l}\text { Periarticular } \\
\text { ossification }\end{array}$ & $3(20)$ & 0 \\
\hline Osteoarthritis & $3(20)$ & $1(6.66)$ \\
\hline $\begin{array}{l}\text { Proximal radial } \\
\text { migration }\end{array}$ & $5(33.33)$ & $1(6.66)$ \\
\hline Persistent wrist pain & $5(33.33)$ & $1(6.66)$ \\
\hline $\begin{array}{l}\text { Loosening of } \\
\text { prosthesis }\end{array}$ & - & 0 \\
\hline $\begin{array}{l}\text { Posterior } \\
\text { interosseous nerve } \\
\text { palsy }\end{array}$ & 0 & 0 \\
\hline $\begin{array}{l}\text { Postero-lateral } \\
\text { instability }\end{array}$ & $4(26.66)$ & $1(6.66)$ \\
\hline Total patients & 15 & 15 \\
\hline
\end{tabular}

\section{DISCUSSION}

Until late 1970's, radial head excision remained the mainstay of treatment in Mason type III radial head fractures. It was later documented that after the medial collateral ligament, the radial head is the second most 
important valgus stabilizer at the elbow joint. With improvement in surgical techniques and advent in the field of instrumentation, radial head reconstruction started becoming a popular option by the end of 19990's. ${ }^{29,30}$

Our study was a randomized prospective study with DASH score being used for measuring the functional outcome after surgery at follow up periods of 6 weeks, 3 month and 6 months.

It was evident that patients treated with hemiarthroplasty with radial head prosthesis displayed a significantly superior DASH score at each follow up as compared to patients treated with radial head excision arthroplasty ( $p<0.05$ at each follow up). This was comparable to a study of 28 patients with Mason type III radial head fractures who underwent radial head resection versus hemiarthroplasty with radial head prosthesis conducted by Ikeda et al, who reported that the radial head resection group lost more strength, range of supination and pronation movements than the open reduction and internal fixation group. ${ }^{31}$

Five patients $(33.33 \%)$ in the radial head excision group reported with proximal radial migration, leading to persistent wrist pain, whereas only one $(6.66 \%)$ such case was reported in the radial head prosthesis group. Periarticular ossification and osteoarthritis of the elbow was observed in three $(20 \%)$ patients in radial head excision group and only one $(6.66 \%)$ patient in radial head prosthesis group. No cases of prosthesis loosening or posterior interosseous nerve damage were reported in our study. These findings are similar to those of Mikic and colleagues, who showed proximal radial migration in 47 percent of their patients, osteoarthritis in 52 percent, and periarticular ossification in 57 percent. $^{32}$

Hemiarthroplasty with radial head prosthesis is technically a more demanding option and needs fairer surgical skills as well as equipments. However, it results in better restoration of elbow stability, flexion and extension at the joint and rotational movement of the forearm. In cases of severe comminution, radial head excision can lead to marked instability, impaired mobility at the elbow joint and long-term pain at the elbow joint, wrist joint and even the forearm. Proximal radial migration as seen in followup cases of radial head fractures treated with excision arthroplasty often lead to distal radio-ulnar joint disruptions, distal radio-ulnar joint arthritis, persistent pain at the wrist and lateral aspect of the elbow and markedly diminished grip strength . The structural deficit caused at the elbow following a radial head excision arthroplasty with due time also leads to ulno-humeral osteoarthritic changes. Arthroplasty with a metal radial head prosthesis is an appealing modality in such cases.

\section{CONCLUSION}

Keeping the limitations of the present study in mind i.e. a small sample size and a short follow up period, it is safe to deduce that Mason type III radial head fractures treated with hemiarthroplasty with radial head prosthesis result in better functional outcome at the elbow joint and have shown to have lower complication rates as compared to those treated with excision arthroplasty. The authors report no conflict of interests.

Funding: No funding sources

Conflict of interest: None declared

Ethical approval: The study was approved by the institutional ethics committee

\section{REFERENCES}

1. Karlsson MK, Herbertsson P, Nordqvist A, Besjakov J, Josefsson PO, Hasserius R. Comminuted fractures of the radial head. Acta Orthop. 2010;81(2):224-7.

2. Caputo AE, Mazzocca AD, Santoro VM. The nonarticulating portion of the radial head: Anatomic and clinical correlations for internal fixation. J Hand Surg Am. 1998;23(6):1082-90.

3. Bryce CD, Armstrong AD. Anatomy and biomechanics of the elbow. Orthop Clin North Am. 2008;39(2):141-54.

4. Yamaguchi K, Sweet FA, Bindra R, Morrey BF, Gelberman RH. The extraosseous and intraosseous arterial anatomy of the adult elbow. J Bone Joint Surg Am. 1997;79(11):1653-62.

5. Morrey BF, An KN, Stormont TJ. Force transmission through the radial head. J Bone Joint Surg Am. 1988;70(2):250-6.

6. Jensen SL, Olsen BS, Tyrdal S, Søjbjerg JO, Sneppen O. Elbow joint laxity after experimental radial head excision and lateral collateral ligament rupture: efficacy of prosthetic replacement and ligament repair. J Shoulder Elbow Surg. 2005;14(1):78-84.

7. Morrey BF, An KN. Articular and ligamentous contributions to the stability of the elbow joint. Am J Sports Med. 1983;11(5):315-9.

8. Sellman DC, Seitz WH Jr, Postak PD, Greenwald AS. Reconstructive strategies for radioulnar dissociation: A biomechanical study. J Orthop Trauma. 1995;9(6):516-22.

9. Morrey BF, Tanaka S, An KN. Valgus stability of the elbow. A definition of primary and secondary constraints. Clin Orthop Relat Res. 1991;265:187-95.

10. Schneeberger AG, Sadowski MM, Jacob HA. Coronoid process and radial head as posterolateral rotatory stabilizers of the elbow. J Bone Joint Surg Am. 2004;86(5):975-82.

11. Shepard MF, Markolf KL, Dunbar AM. Effects of radial head excision and distal radial shortening on load-sharing in cadaver forearms. J Bone Joint Surg Am. 2001;83(1):92-100.

12. Beingessner DM, Dunning CE, Gordon KD, Johnson JA, King GJ. The effect of radial head excision and arthroplasty on elbow kinematics and stability. J Bone Joint Surg Am. 2004;86(8):1730-9. 
13. Ruchelsman DE, Christoforou D, Jupiter JB. Current Concepts Review: Fracture of the radial head and neck. J Bone Joint Surg Am. 2013;95:469-78.

14. Duckworth AD, McQueen MM, Ring D. Fractures of the radial head. Bone Joint J. 2013;95(2):151-9.

15. Charalambous CP, Stanley JK, Mills SP, Hayton MJ, Hearnden A, Trail I, et al. Comminuted radial head fractures: aspects of current management. J Shoulder Elbow Surg. 2011;20(6):996-1007.

16. Ring D. Radial head fracture: open reduction-internal fixation or prosthetic replacement. J Shoulder Elbow Surg. 2011;20(2):107-12.

17. Mason ML. Some observations on fracture of the head of the radius with a review of one hundred cases. Br J Surg. 1954;42:123-32.

18. Broberg MA, Morrey BF. Results of treatment of fracture-dislocations of the elbow. Clin Orthop Relat Res. 1987;216:109-19.

19. Sellman DC, Seitz WH Jr, Postak PD, Greenwald AS. Reconstructive strategies for radioulnar dissociation: A biomechanical study. J Orthop Trauma. 1995;9(6):516-22.

20. King GJ, Zarzour ZD, Rath DA, Dunning CE, Patterson SD, Johnson JA. Metallic radial head arthroplasty improves valgus stability of the elbow. Clin Orthop Relat Res. 1999;368:114-25.

21. Bain GI, Ashwood N, Baird R, Unni R. Management of Mason type-III radial head fractures with a titanium prosthesis, ligament repair, and early mobilization. Surgical technique. J Bone Joint Surg Am. 2005;87(1):136-47.

22. King GJ, Zarzour ZD, Patterson SD, Johnson JA. An anthropometric study of the radial head: implications in the design of a prosthesis. J Arthroplasty. 2001;16(1):112-6.

23. Kaas L, Struijs PA, Ring D, van Dijk CN, Eygendaal D. Treatment of Mason type II radial head fractures without associated fractures or elbow dislocation: a systematic review. J Hand Surg Am. 2012;37(7):1416-21.

24. Pomianowski S, Morrey BF, Neale PG, Park MJ, O'Driscoll SW, An KN. Contribution of monoblock and bipolar radial head prostheses to valgus stability of the elbow. J Bone Joint Surg Am. 2001;83(12):1829-34.

25. Moungondo F, El Kazzi W, van Riet R, Feipel V, Rooze M, Schuind F. Radiocapitellar joint contacts after bipolar radial head arthroplasty. J Shoulder Elbow Surg. 2010;19(2):230-5.

26. Hartzler RU, Morrey BF, Steinmann SP, Llusa-Perez M, Sanchez-Sotelo J. Radial head reconstruction in elbow fracture-dislocation: monopolar or bipolar prosthesis? Clin Orthop Relat Res. 2014;472(7):2144-50.

27. Barnes LF, Lombardi J, Gardner TR, Strauch RJ, Rosenwasser MP. Comparison of Exposure in the Kaplan Versus the Kocher Approach in the Treatment of Radial Head Fractures. Hand (N Y). 2019;14(2):253-8.

28. Gummesson C, Atroshi I, Ekdahl C. The disabilities of the arm, shoulder and hand (DASH) outcome questionnaire: longitudinal construct validity and measuring self-rated health change after surgery. BMC Musculoskelet Disord. 2003;4:11.

29. Ring D, Jupiter JB. Monteggia fractures in adults. J Bone Joint Surg. 1998;80:1733-44.

30. Morrey BF, Askew L, Chao EY. Silastic prosthetic replacement for the radial head. J Bone Joint Surg. 1981;63:454-58.

31. Ikeda M, Sugiyama K, Kang C, Takagaki T, Oka Y. Comminuted Fractures of the Radial Head: Comparison of Resection and Internal Fixation Surgical Technique. JBJS. 2006;88:11-23.

32. Zarattini G, Galli S, Marchese M, Di Mascio L, Pazzaglia UE. The surgical treatment of isolated Mason type 2 fractures of the radial head in adults: comparison between radial head resection and open reduction and internal fixation. J Orthop Trauma. 2012;26:229-35.

Cite this article as: Kumar P, Patil NS, Nikam MA. Functional outcome of elbow after comminuted radial head fractures treated with radial head excision arthroplasty versus radial head prosthesis. Int J Res Orthop 2022;8:197-202. 